\title{
Targeting Conventional Dendritic Cells to Fine-Tune Antibody Responses
}

\author{
Demo Yemane Tesfaye ${ }^{1,2 \dagger}$, Arnar Gudjonsson ${ }^{1,3 \dagger}$, Bjarne Bogen ${ }^{1,2,3}$ and Even Fossum ${ }^{1,2 *}$ \\ ${ }^{1}$ K. G. Jebsen Center for Research on Influenza Vaccines, Oslo University Hospital, University of Oslo, Oslo, Norway, \\ ${ }^{2}$ Department of Immunology and Transfusion Medicine, Oslo University Hospital, Oslo, Norway, ${ }^{3}$ Institute of Clinical \\ Medicine, Oslo University Hospital, University of Oslo, Oslo, Norway
}

Dendritic cells (DCs) facilitate cross talk between the innate and adaptive immune system. They sense and phagocytose invading pathogens, and are not only capable of activating naiive $T$ cells, but can also determine the polarization of $T$ cell responses into different effector subtypes. Polarized T cells in turn have a crucial role in antibody class switching and affinity maturation, and consequently the quality of the resulting humoral immunity. Targeting vaccines to DCs thus provides a great deal of opportunities for influencing the humoral immune responses, by fine-tuning the $T$ cell response as well as regulating antigen availability for B cells. In this review we aim to outline how different DC targeted vaccination strategies can be utilized to induce a desired humoral immune response. A range of factors, including route of vaccine administration, use of adjuvants, choice of DC subset and surface receptor to target have been reported to influence the resulting immune response and will be reviewed herein. Finally, we will discuss opportunities for designing improved vaccines and challenges with translating this knowledge into clinical or veterinary medicine.

Keywords: dendritic cell (DC), DC subtypes, vaccination, targeting, antibody, Th1 \& Th2

\section{INTRODUCTION}

Conventional dendritic cells (cDCs) are divided into two sub-populations, $\mathrm{cDC} 1 \mathrm{~s}$ and cDC2s, based on ontogenic and functional differences [reviewed in $(1,2)]$. Both populations are derived from pre-cDCs that develop in the bone barrow, before migrating to secondary lymphoid or peripheral tissue where the final differentiation into $\mathrm{cDC} 1 \mathrm{~s}$ and $\mathrm{cDC} 2 \mathrm{~s}$ occurs (3-5). Differentiation into CDC1s is dependent on the transcription factors IRF8 (6) and Id2 (7), and to a lesser extent BATF3 $(8,9)$, while cDC2 differentiation is dependent on IRF4 $(10,11)$. Both cDC1s and cDC2s can present antigen-derived peptides on MHC-II to $\mathrm{CD} 4^{+} \mathrm{T}$ cells, although studies have reported that cDC2s are more efficient at this process $(12,13)$. In contrast, only cDC1s efficiently cross-present antigens to $\mathrm{CD} 8^{+} \mathrm{T}$ cells in mice (13-15).

Due to their crucial role in the induction of T cell responses, delivery of antigen to DCs has been extensively evaluated in various cancer and infectious disease models [reviewed in (16)]. However, targeting antigen to DCs can also enhance antibody responses. Indeed, early studies where avidin was conjugated to biotinylated anti-MHC-II antibodies resulted in improved induction of anti-avidin antibodies in the absence of adjuvant (17). However, since MHC-II is also expressed on B cells and other antigen presenting cells (APC), it was unclear to what extent DC targeting 
contributed to the improved antibody responses. Wang and colleagues later observed that targeting the pan-DC marker CD11c also resulted in enhanced antibody responses, highlighting DCs as an attractive target for enhancing humoral responses (18). Here, we review the current literature on how delivering antigens to $\mathrm{CDCs}$ can be utilized to enhance both the polarization and the magnitude of the humoral response, and discuss how different immunization strategies can be utilized to fine-tune the antibody responses.

\section{ANTIBODY POLARIZATION AS A FUNCTION OF DC SUBTYPE}

DCs are effective in priming naïve $\mathrm{CD} 4^{+} \mathrm{T}$ cells into functionally distinct effector $\mathrm{T}$ helper (Th) cells, with different subsets of DCs dictating differential effector T cell commitment $(19,20)$. cDC1s promote development of T helper 1 (Th1) cells through secretion of IL-12 (21), while cDC2s secrete IL-10 and IL-33 and drive Th2 responses (22) (Figure 1). In addition, cDC2s are important for efficient induction of $\mathrm{T}$ follicular helper $\left(\mathrm{T}_{\mathrm{FH}}\right)$ cells $(23,24)$. It is less clear to what extent $\mathrm{cDC} 1 \mathrm{~s}$ influence $\mathrm{T}_{\mathrm{FH}}$ induction, but they have been reported to do so under inflammatory conditions (25). Also, studies have shown that IL12 secreting DCs can promote $\mathrm{T}_{\mathrm{FH}}$ induction in humans $(26,27)$. The different $\mathrm{T}$ helper subtypes, through secretion of different cytokines, will in turn influence the magnitude and nature of humoral immune responses mounted by B cells $(28,29)$. For instance, secretion of IL-21 by $\mathrm{T}_{\mathrm{FH}}$ cells induces differentiation of naïve and memory $\mathrm{B}$ cells into antibody secreting plasma cells $(26,30,31)$. Furthermore, the characteristic Th1 cytokine IFN- $\gamma$ promotes induction of IgG2a class switching, while the Th2 associated IL-4 drives class switching toward IgG1, in mice (Figure 1) $(32,33)$. Recent studies have identified subtypes of $\mathrm{T}_{\mathrm{FH}}$, now often referred to as Tfh1 and Tfh2, as the source of IFN- $\gamma$ and IL-4, respectively (34). However, induction of IgG2c has been observed in mice deficient of $\mathrm{T}_{\mathrm{FH}}$ cells, suggesting that Th1 cells may be sufficient for class switching (35).

Mice have four subtypes of IgG: IgG1, IgG2b, IgG3, and depending on the strain, IgG2a in BALB/C or IgG2c in C57BL/6 $(31,36)$. The fragment crystallizable $(\mathrm{Fc})$ region of the different IgG subtypes binds to specific Fc-receptors ( $\mathrm{Fc} \gamma \mathrm{Rs}$ ) and modulate subsequent effector cell functions (37). In mice there are three activating Fc $\gamma$-receptors (Fc $\gamma$ RI, Fc $\gamma$ RIII, Fc $\gamma$ RIV) and one inhibitory Fc $\gamma$-receptor (Fc $\gamma$ RIIB) (38). IgG2a and IgG2b are reported to have higher affinity for the activating $\mathrm{Fc} \gamma$ receptors which result in pro-inflammatory responses (39) and antibody-dependent cytotoxicity (ADCC) (40). In contrast, IgG1 has higher affinity for the inhibitory FcyRIIB, and therefore contributes to dampening the inflammatory response (41).

Several recent studies have observed that antibodies directed against certain viral antigens heavily rely on Fc-mediated effector functions to provide protection. For instance, broadly neutralizing antibodies against HIV gp120 are more efficient as IgG2c subtype compared to IgG1 (42). Similar observations have been made with broadly neutralizing antibodies against the stem-region (43) or head-region (44) of influenza hemagglutinin
(HA), and the highly conserved influenza M2e antigen $(45,46)$. In humans, IgG3 is one of the subtypes with high affinity for activating Fc $\gamma$-receptors, and consequently mediates strong effector functions (38). Interestingly, a large phase $3 \mathrm{HIV}$ vaccine trial in Thailand observed a correlation between IgG3 titers and partial protection against HIV infection (47).

Together, these studies demonstrate how DC subsets, through $\mathrm{T}$ cell polarization, can influence antibody subclass polarization and consequently vaccine efficacy. They also raise the intriguing possibility of delivering different antigens to $\mathrm{CDC} 1 \mathrm{~s}$ or $\mathrm{cDC} 2 \mathrm{~s}$ at the same time, and eliciting different polarized immune responses to different antigens. Such approaches could be of value in the development of vaccines against more complex microorganisms, such as Mycobacterium tuberculosis, where conventional vaccine technology has yet to produce an efficient vaccine.

\section{TARGETING DIFFERENT DC RECEPTORS IMPACTS ANTIBODY POLARIZATION}

The propensity of the different DC subtypes to elicit different arms of the adaptive immune response creates opportunities for fine-tuning of vaccine induced immune responses. In accordance with the described role of DC subsets, targeting influenza HA to $\mathrm{cDC} 1 \mathrm{~s}$ by fusion to the chemokine $\mathrm{Xcl1}$, the ligand for the $\mathrm{cDC} 1$ restricted receptor Xcr1 $(48,49)$, induces Th1 cells and antibody responses dominated by the IgG2a subclass (5052). Similarly, targeting the model antigen ovalbumin (OVA) to the C-type lectin DEC-205 on cDC1s has also been shown to increase IgG2a and IgG2b responses compared non-targeted controls (53). However, targeting the $\mathrm{cDC1}$ restricted C-type lectin Clec9a has been reported to induce more of a mixed IgG1/IgG2a response, suggesting that the choice of the targeted receptor also influences the antibody polarization, and not just the targeted DC subset. The enhanced induction of IgG1 may be related to the increased $\mathrm{T}_{\mathrm{FH}}$ induction observed when targeting antigen to Clec9a (54).

Delivering antigen to surface receptors expressed on $\mathrm{cDC} 2 \mathrm{~s}$, such as toll like receptor 5 (TLR5) or DC-inhibitory factor 2 (DCIR2), results in antibody responses of the IgG1 subclass $(52,55)$. However, the exact mechanism of Th differentiation and whether or not germinal center (GC) formation is enhanced during DCIR2 targeting is less clear. For instance, Chappell and colleagues reported that during DCIR2 targeted vaccination, Tfh differentiation is achieved indirectly through activation of extrafollicular B cells, which ultimately results in an IgG1 response (55). In this study, it was reported that DCIR2 targeting failed to induce germinal center formation (55). However, Shin et al. $(24,56)$ have reported that DCIR2 targeted vaccination in the presence of poly(I:C) or LPS is capable of efficiently inducing $\mathrm{GC}$ formation and $\mathrm{T}_{\mathrm{FH}}$ differentiation.

In a comparative study, Do and colleagues targeted antigen from Yersinia pestis to DEC-205 or DCIR2, and observed distinct cytokine profile associated with Th1 or Th2 polarization, respectively (57). Consistent with these observations, targeting CIRE and FIRE (C-type lectin family receptors on murine 


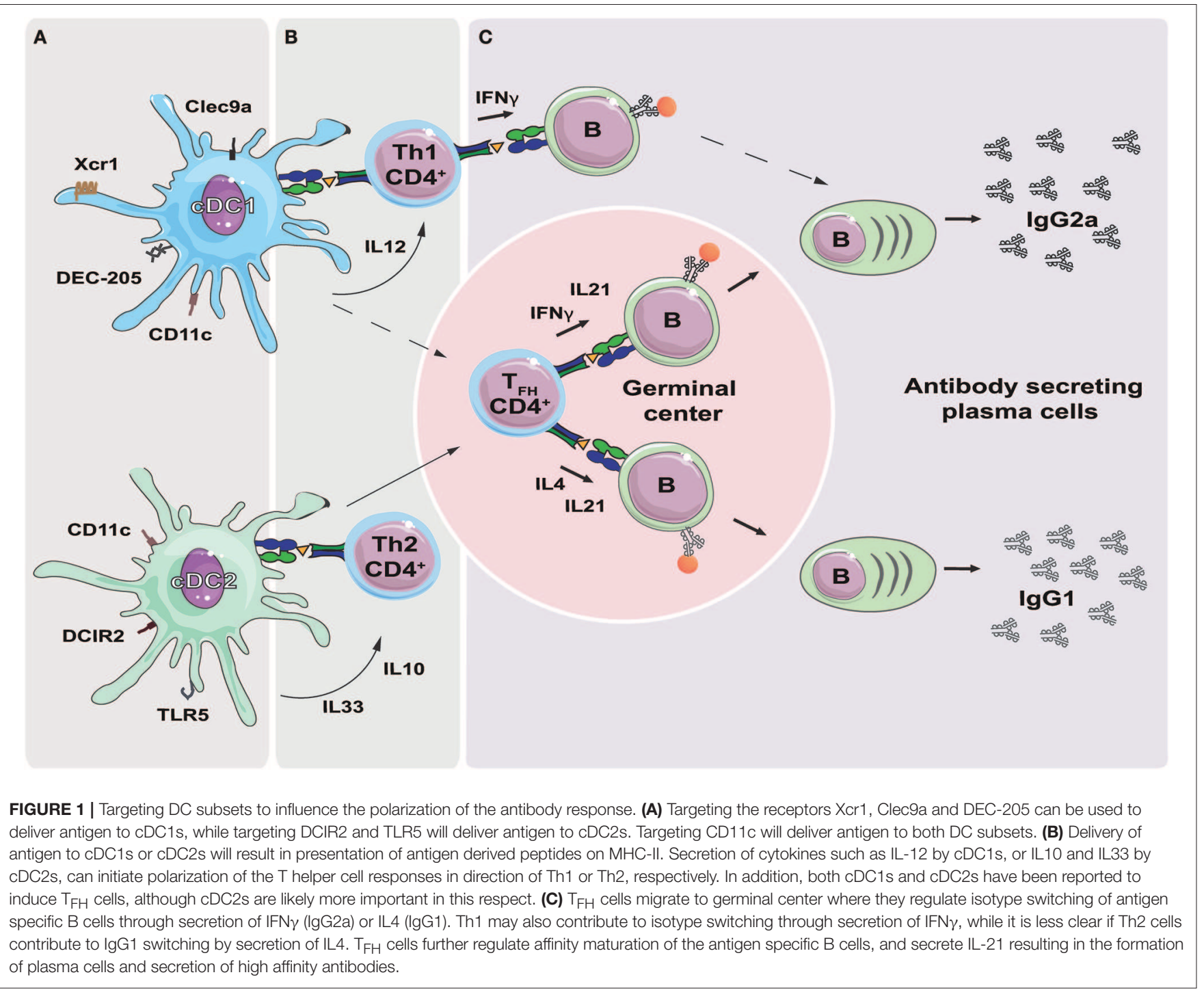

cDC2s) using rat anti-CIRE and anti-FIRE antibodies results in enhanced antibody production of the IgG1 subtype compared to rat anti-DEC-205 antibodies (58). In this study, the antibody profile obtained from targeting $\mathrm{cDC} 2 \mathrm{~s}$ was limited to IgG1, while DEC-205 targeting induced IgG2a, and IgG3 responses mixed with IgG1 (58). Consequently, targeting $\mathrm{cDC1}$ or CDC2 predominantly polarize the antibody response toward $\operatorname{IgG} 2 \mathrm{a} / \operatorname{IgG} 2 \mathrm{c}$ or IgG1, respectively.

Targeting antigen to surface receptors expressed on both cDC1s and cDC2s, such as CD11c or MHC-II, have yielded antibody responses dominated by the IgG1 subclass $(18,52,59)$. One potential explanation for this observation is that $\mathrm{cDC} 2 \mathrm{~s}$ constitute $80-90 \%$ of the cDCs in secondary lymphoid organs $(60,61)$, and would therefore be more likely to obtain the antigen. Interestingly, fusing influenza $\mathrm{HA}$ to the chemokine CCL3, a ligand for CCR3 and CCR5 expressed on both CDC1s and $\mathrm{cDC} 2 \mathrm{~s}$, resulted in a more mixed IgG1 and IgG2a response $(62,63)$. Adding to the complexity, vaccine delivery site may also contribute to the polarization of the antibody response. For example, we recently observed that CCL3-HA induced a significantly more Th1 polarized antibodies response after intramuscular DNA immunization compared to intradermal DNA immunization (63), despite reports of similar ratio of cDC1s to cDC2s in the two tissues $(15,64)$.

It should be noted that adjuvants also influence immune responses during $\mathrm{cDC} 1$ and $\mathrm{cDC} 2$ targeted vaccinations. At steady state, immature DCs tend to induce tolerogenic responses [reviewed in (65)] while presence of adjuvants stimulates upregulation of maturation markers and abrogates tolerance induction (66). During DEC-205 targeted cDC1 vaccinations, coadministration of adjuvants was important in inducing immune responses (58). However, targeting Clec9a, another receptor on $\mathrm{CDC} 1$, is reported to be immunogenic even in the absence of adjuvants (54). Furthermore, presence of adjuvants influences the efficiency of DCIR2 targeting on formation of GC reactions and $\mathrm{T}_{\mathrm{FH}}$ polarization $(24,55,56)$. Of note here is that adjuvants 
may act on other immune cells than cDCs to dictate the immune outcome. For instance, a synthetic hemozoin adjuvant has recently been shown to interact directly with $\mathrm{B}$ cells and enhance IgG2c class switching (67). In this regard, addition of Th1 polarizing adjuvant can boost the induction of Th1 associated IgG subclasses even when delivering antigens to cDC2s. For instance, targeting antigen to DCIR2 in the presence of anti-CD40 and polyI:C increased titers of both the Th1 (IgG2c or IgG2a) and the Th2 (IgG1) subclasses (57, 68). All in all, the variation in choice of vaccine design coupled with differences in adjuvants used, makes the direct comparison of DC targeted vaccination from different studies difficult. Therefore, comparative investigations of antibody polarization profiles after targeting DCs using similar vaccine platforms is crucial.

\section{MAGNITUDE OF THE ANTIBODY RESPONSE}

While the ability to impact the polarization of the antibody response is important, the magnitude and the affinity of the antibodies will ultimately determine whether the vaccine is protective or not. With regards to achieving good antibody responses, Clec9a has been reported to be a promising targeting candidate in mice using the model antigen OVA as well as the influenza antigen M2e and the hand, foot and mouth diseasecausing enterovirus 71 antigen SP70 $(54,69)$. This effect of Clec9a targeting has in part been attributed to efficient induction of $\mathrm{T}_{\mathrm{FH}}$ cells $(54,70)$. Targeting antigen to the pan-DC marker CD11c has also resulted in high antibody titers as well as improved germinal center responses $(18,71)$. While CD11c, and especially Clec9a, are predominantly expressed on cDCs, there are other markers worth mentioning that are not as DC specific. For instance, targeting influenza HA to MHC-II or NP and OVA to CD180 have resulted in strong antibody responses (59, 71-73). While both of these markers are expressed on DCs, they are not DC specific. Indeed, it is the proliferation and differentiation of the $\mathrm{B}$ cells that has been shown to be of importance in inducing antibody responses upon targeting CD180 (73). Similarly, Andersen et al recently used adoptively transferred B cells to show that targeting MHC-II exclusively on $\mathrm{B}$ cells, in the absence of DCs, is sufficient to increase antibody production (74).

\section{MODULATING ANTIGEN AVAILABILITY KINETICS TO INCREASE ANTIBODY RESPONSES}

Recently, the augmentation of vaccine induced antibody responses through modulation of antigen availability kinetics has emerged as a promising strategy in rational vaccine design. Encouraging findings in mice using HIV Env trimers or HIV gp120 as antigen have shown that prolonged antigen release gives better antibody responses when compared to bolus vaccination-an effect that may be further improved by exponentially increasing the immunization dose $(75,76)$. Studies in non-human primates have shown similar effects $(77,78)$, demonstrating the translational potential of this immunization strategy. One possible explanation for the improved antibody responses may be that these vaccination strategies more closely mimic antigen availability kinetics of natural infections. Further beneficial effects of prolonged antigen availability applied to vaccinations are reviewed in more detail elsewhere (79).

The objective of DC targeted vaccine strategies is the manipulation of antigen delivery to DCs, which in turn directly affects antigen availability for B cells. This latter aspect presents opportunities that perhaps have not been fully appreciated in the field. Targeting strategies could be designed to optimize the antigen availability kinetics for B cells in order to augment the antibody response, aiming to achieve the same effects as those seen with prolonged antigen release in the above-mentioned studies. For instance, we have observed that when targeting hemagglutinin influenza $\mathrm{HA}$ to the $\mathrm{Xcrl}$ receptor on $\mathrm{cDC} 1 \mathrm{~s}$ in a manner that does not result in receptor activation and internalization, the ensuing GC and antibody responses were greater than when the vaccine was actively endocytosed $(51,80)$. A strength in our approach is that we directly compare targeting to the same receptor on $\mathrm{cDC1}$ s in a manner that either induces endocytosis or not, while keeping all other variables constant. Similarly, the strong antibody responses observed when targeting Clec9a are suggested to be due to high specificity of Clec9a expression resulting in long half-life of the vaccine molecule in serum after immunization, thus prolonging availability of the antigen to B cells (54). Notably, a DEC-205 targeted vaccine in the same study had a shorter half-life and was less efficient in inducing antibody responses (54). These effects were obtained in the absence of adjuvants, supporting the notion that they were purely due to the nature of the targeting.

Finally, the choice of delivery method may affect the antigen availability kinetics. For instance, DNA vaccination may result in more optimal antigen availability kinetics than bolus protein vaccination. The antigen will be produced and released over a prolonged time, more resembling a natural infection and delivering fresh and intact antigen to the GC response after its initiation. Nevertheless, DC targeting strategies aiming to achieve good antibody responses should be designed with the B cell antigen availability kinetics in mind, whether they are based on DNA or protein immunization.

From these observations, we can summarize that targeted vaccines that are less efficiently taken up and degraded by DCs are more likely to be potent in inducing antibody responses. Such vaccines may result in more antigen being available in the lymph nodes for a longer period of time, potentiating the GC reaction. Additionally, if the vaccine molecule stays on the DC surface, it might interact with and recruit $B$ cells entering the draining lymph node through high endothelial venules in the form of a DC-B cell synapse (81).

\section{TRANSLATION TO CLINICAL MEDICINE}

Translating vaccine strategies aimed at delivering antigen to DCs to humans present a number of challenges. First, DC subsets in mice and humans have until recently been defined by different 
surface markers, making it challenging to compare observations between the different species. However, with the discovery of more conserved markers for cDC1s such as XCR1 (82-84), CLEC9A (85-87), and for cDC2s such as SIRP1a (60), more accurate strategies for defining DC populations in both man and mouse have become available (60). Second, expression of specific surface markers may vary between species. For example, DEC-205 has been reported to have a broader expression pattern in humans compared to mice (88), adding uncertainty to how pre-clinical data from mice will translate to humans. Third, it is unclear to what extent the functional separation of $\mathrm{cDC} 1 \mathrm{~s}$ and $\mathrm{cDC} 2 \mathrm{~s}$ seen in mice is conserved in humans. For instance, cross-presentation to $\mathrm{CD}^{+} \mathrm{T}$ cells and induction of Th1 cells has been associated with $\mathrm{cDC} 1 \mathrm{~s}$ in mice. In humans, however, both $\mathrm{cDC} 1 \mathrm{~s}$ and $\mathrm{CDC} 2 \mathrm{~s}$ have been reported to cross-present antigen (89), secrete IL-12 and promote Th1 polarization $(90,91)$. Nevertheless, clinical trials have demonstrated that targeting the tumor antigen NY-ESO-1 to DEC-205 induced antigen specific antibodies (92). The antibody responses were dominated by IgG1, which is functionally more similar to the IgG2a subclass in mice (38).

While delivering antigen to DEC-205 is the only DC targeting strategy to have entered into clinical trials so far, studies in other animal models have been reported. Immunization of Macaques with a rat antibody specific for Macaque CLEC9A resulted in strong anti-rat IgG antibody responses in the absence of adjuvant (93). In pigs, targeting the influenza antigen $\mathrm{M} 2 \mathrm{e}$ to $\mathrm{cDC} 1 \mathrm{~s}$ by fusion to porcine XCL1 enhanced antibody responses in both naive and sero-positive animals (94). Also in pigs, targeting the influenza antigen nucleoprotein (NP) to CD11c induced strong antibody responses, although the responses were not

\section{REFERENCES}

1. Guilliams M, Ginhoux F, Jakubzick C, Naik SH, Onai N, Schraml BU, et al. Dendritic cells, monocytes and macrophages: a unified nomenclature based on ontogeny. Nat Rev Immunol. (2014) 14:571-8. doi: 10.1038/nri3712

2. Guilliams M, Henri S, Tamoutounour S, Ardouin L, Schwartz-Cornil I, Dalod M, et al. From skin dendritic cells to a simplified classification of human and mouse dendritic cell subsets. Eur J Immunol. (2010) 40:2089-94. doi: 10.1002/eji.201040498

3. Naik SH, Metcalf D, van Nieuwenhuijze A, Wicks I, Wu L, O'Keeffe M, et al. Intrasplenic steady-state dendritic cell precursors that are distinct from monocytes. Nat Immunol. (2006) 7:663-71. doi: 10.1038/ni1340

4. Diao J, Winter E, Chen W, Cantin C, Cattral MS. Characterization of distinct conventional and plasmacytoid dendritic cell-committed precursors in murine bone marrow. J Immunol. (2004) 173:1826-33. doi: 10.4049/jimmunol.173.3.1826

5. Liu K, Victora GD, Schwickert TA, Guermonprez P, Meredith MM, Yao K, et al. In vivo analysis of dendritic cell development and homeostasis. Science. (2009) 324:392-7. doi: 10.1126/science.1170540

6. Schiavoni G, Mattei F, Sestili P, Borghi P, Venditti M, Morse HC III, et al. ICSBP is essential for the development of mouse type I interferon-producing cells and for the generation and activation of CD $8 \alpha(+)$ dendritic cells. J Exp Med. (2002) 196:1415-25. doi: 10.1084/jem.20021263

7. Ginhoux F, Liu K, Helft J, Bogunovic M, Greter M, Hashimoto D, et al. The origin and development of nonlymphoid tissue CD103+ DCs. J Exp Med. (2009) 206:3115-30. doi: 10.1084/jem.20091756 enhanced compared to non-targeted controls (95). With more DC targeting strategies being evaluated in multiple species, we should obtain a better understanding of how characteristics like Th1/Th2 polarization and magnitude of the antibody response translate from mouse studies.

\section{CONCLUDING REMARKS}

Delivering antigens to cDCs has garnered much attention as a method for enhancing $\mathrm{CD}^{+} \mathrm{T}$ cell responses. We strongly believe that the potential to influence $\mathrm{CD}^{+}{ }^{+} \mathrm{T}$ cell polarization, and consequently antibody class switching, are of equal importance. Especially when considering the observations that IgG-subclass and Fc-mediated effector functions strongly influence the protective ability for broadly neutralizing antibodies against influenza and HIV. When also considering the ability to actively manipulate the magnitude and quality of the antibody responses, DC targeting will be a valuable tool for further vaccine development.

\section{AUTHOR CONTRIBUTIONS}

All authors listed have made a substantial, direct and intellectual contribution to the work, and approved it for publication.

\section{FUNDING}

Research Council of Norway FRIPRO project 250884 (EF) provides funding for DT and EF. Stiftelsen Kristian Gerhard Jebsen, K. G. Jebsen Center For Influenza Vaccine Research (BB) provides funding for AG.
8. Hildner K, Edelson BT, Purtha WE, Diamond M, Matsushita H, Kohyama $M$, et al. Batf3 deficiency reveals a critical role for $\mathrm{CD} 8 \alpha+$ dendritic cells in cytotoxic T cell immunity. Science. (2008) 322:1097-100. doi: 10.1126/science.1164206

9. Tussiwand R, Lee WL, Murphy TL, Mashayekhi M, Kc W, Albring JC, et al. Compensatory dendritic cell development mediated by BATF-IRF interactions. Nature. (2012) 490:502-7. doi: 10.1038/nature11531

10. Suzuki S, Honma K, Matsuyama T, Suzuki K, Toriyama K, Akitoyo I, et al. Critical roles of interferon regulatory factor 4 in CD11bhighCD8alphadendritic cell development. Proc Natl Acad Sci USA. (2004) 101:8981-6. doi: 10.1073/pnas.0402139101

11. Tamura T, Tailor P, Yamaoka K, Kong HJ, Tsujimura H, O’Shea $\mathrm{JJ}$, et al. IFN regulatory factor- 4 and -8 govern dendritic cell subset development and their functional diversity. J Immunol. (2005) 174:2573-81. doi: 10.4049/jimmunol.174.5.2573

12. Dudziak D, Kamphorst AO, Heidkamp GF, Buchholz VR, Trumpfheller C, Yamazaki S, et al. Differential antigen processing by dendritic cell subsets in vivo. Science. (2007) 315:107-11. doi: 10.1126/science.11 36080

13. Pooley JL, Heath WR, Shortman K. Cutting edge: intravenous soluble antigen is presented to CD4 T cells by CD8- dendritic cells, but cross-presented to CD8 T cells by CD8+ dendritic cells. J Immunol. (2001) 166:5327-30. doi: 10.4049/jimmunol.166.9.5327

14. Bedoui S, Whitney PG, Waithman J, Eidsmo L, Wakim L, Caminschi I, et al. Cross-presentation of viral and self antigens by skin-derived CD103+ dendritic cells. Nat Immunol. (2009) 10:488-95. doi: 10.1038/ni.1724 
15. Henri S, Poulin LF, Tamoutounour S, Ardouin L, Guilliams M, de Bovis B, et al. CD207+ CD103+ dermal dendritic cells cross-present keratinocytederived antigens irrespective of the presence of Langerhans cells. J Exp Med. (2009) 207:189-206. doi: 10.1084/jem.20091964

16. Kastenmuller W, Kastenmuller K, Kurts C, Seder RA. Dendritic cell-targeted vaccines-hope or hype? Nature reviews. Immunology. (2014) 14:705-11. doi: $10.1038 /$ nri3727

17. Carayanniotis G, Barber BH. Adjuvant-free IgG responses induced with antigen coupled to antibodies against class II MHC. Nature. (1987) 327:59-61. doi: $10.1038 / 327059 \mathrm{a} 0$

18. Wang H, Griffiths MN, Burton DR, Ghazal P. Rapid antibody responses by low-dose, single-step, dendritic cell-targeted immunization. Proc Natl Acad Sci USA. (2000) 97:847-52. doi: 10.1073/pnas.97.2.847

19. Pulendran B, Smith JL, Caspary G, Brasel K, Pettit D, Maraskovsky E, et al. Distinct dendritic cell subsets differentially regulate the class of immune response in vivo. Proc Natl Acad Sci USA. (1999) 96:1036-41. doi: 10.1073/pnas.96.3.1036

20. Maldonado-Lopez R, De Smedt T, Michel P, Godfroid J, Pajak B, Heirman $\mathrm{C}$, et al. $\mathrm{CD} 8 \alpha+$ and $\mathrm{CD} 8 \alpha-$ subclasses of dendritic cells direct the development of distinct T helper cells in vivo. J Exp Med. (1999) 189:587-92. doi: 10.1084/jem.189.3.587

21. Macatonia SE, Hosken NA, Litton M, Vieira P, Hsieh CS, Culpepper JA, et al. Dendritic cells produce IL-12 and direct the development of Th1 cells from naive CD4+ T cells. J Immunol. (1995) 154:5071-9.

22. Mayer JU, Demiri M, Agace WW, MacDonald AS, Svensson-Frej M, Milling SW. Different populations of CD11b+ dendritic cells drive Th2 responses in the small intestine and colon. Nat Commun. (2017) 8:15820. doi: $10.1038 /$ ncomms 15820

23. Krishnaswamy JK, Gowthaman U, Zhang B, Mattsson J, Szeponik L, Liu D, et al. Migratory $\mathrm{CD} 1 \mathrm{~b}(+)$ conventional dendritic cells induce $\mathrm{T}$ follicular helper cell-dependent antibody responses. Sci Immunol. (2017) 2:eaam9169. doi: 10.1126/sciimmunol.aam9169

24. Shin C, Han JA, Koh H, Choi B, Cho Y, Jeong H, et al. CD8 $\alpha(-)$ dendritic cells induce antigen-specific $\mathrm{t}$ follicular helper cells generating efficient humoral immune responses. Cell Rep. (2015) 11:1929-40. doi: 10.1016/j.celrep.2015.05.042

25. Bouteau A, Kervevan J, Su Q, Zurawski SM, Contreras V, Dereuddre-Bosquet $\mathrm{N}$, et al. DC subsets regulate humoral immune responses by supporting the differentiation of distinct Tfh cells. Front Immunol. (2019) 10:01134. doi: 10.3389/fimmu.2019.01134

26. Schmitt N, Morita R, Bourdery L, Bentebibel SE, Zurawski SM, Banchereau J, et al. Human dendritic cells induce the differentiation of interleukin-21-producing $\mathrm{T}$ follicular helper-like cells through interleukin-12. Immunity. (2009) 31:158-69. doi: 10.1016/j.immuni.2009. 04.016

27. Ma CS, Suryani S, Avery DT, Chan A, Nanan R, Santner-Nanan B, et al. Early commitment of naive human CD4(+) T cells to the T follicular helper $(\mathrm{T}(\mathrm{FH})$ ) cell lineage is induced by IL-12. Immunol Cell Biol. (2009) 87:590-600. doi: 10.1038/icb.2009.64

28. Alam S, Knowlden ZA, Sangster MY, Sant AJ. CD4 T cell help is limiting and selective during the primary B cell response to influenza virus infection. $J$ Virol. (2014) 88:314-24. doi: 10.1128/JVI.02077-13

29. Sette A, Moutaftsi M, Moyron-Quiroz J, McCausland MM, Davies DH, Johnston RJ, et al. elective CD4+ T cell help for antibody responses to a large viral pathogen: deterministic linkage of specificities. Immunity. (2008) 28:847-58. doi: 10.1016/j.immuni.2008.04.018

30. Ettinger R, Sims GP, Fairhurst A-M, Robbins R, da Silva YS, Spolski $\mathrm{R}$, et al. IL-21 induces differentiation of human naive and memory $\mathrm{B}$ cells into antibody-secreting plasma cells. J Immunol. (2005) 175:7867-79. doi: 10.4049/jimmunol.175.12.7867

31. Lu LL, Suscovich TJ, Fortune SM, Alter G. Beyond binding: antibody effector functions in infectious diseases. Nat Rev Immunol. (2018) 18:46-61. doi: $10.1038 /$ nri.2017.106

32. K.-Toellner M, Luther SA, Sze DM-Y, Choy RK-W, Taylor DR, I.MacLennan $\mathrm{CM}$, et al. T helper 1 (Th1) and Th2 characteristics start to develop during $\mathrm{T}$ cell priming and are associated with an immediate ability to induce immunoglobulin class switching. J Exp Med. (1998) 187:1193-204. doi: $10.1084 /$ jem.187.8.1193
33. Mosmann TR, Coffman R. TH1 and TH2 cells: different patterns of lymphokine secretion lead to different functional properties. Annu Rev Immunol. (1989) 7:145-73. doi: 10.1146/annurev.iy.07.040189.001045

34. Reinhardt RL, Liang HE, Locksley RM. Cytokine-secreting follicular T cells shape the antibody repertoire. Nat Immunol. (2009) 10:385-93. doi: $10.1038 /$ ni. 1715

35. Miyauchi K, Sugimoto-Ishige A, Harada Y, Adachi Y, Usami Y, Kaji T, et al. Protective neutralizing influenza antibody response in the absence of $\mathrm{T}$ follicular helper cells. Nat Immunol. (2016) 17:1447-58. doi: 10.1038/ni.3563

36. Collins AM. IgG subclass co-expression brings harmony to the quartet model of murine IgG function. Immunol Cell Biol. (2016) 94:949-54. doi: $10.1038 /$ icb. 2016.65

37. Nimmerjahn F, Ravetch JV. Fcgamma receptors: old friends and new family members. Immunity. (2006) 24:19-28. doi: 10.1016/j.immuni.2005.11.010

38. Nimmerjahn F, Ravetch JV. Fc $\gamma$ receptors as regulators of immune responses. Nat Rev Immunol. (2008) 8:34. doi: 10.1038/nri2206

39. Nimmerjahn F, Bruhns P, Horiuchi K, Ravetch JV. FcgammaRIV: a novel FcR with distinct IgG subclass specificity. Immunity. (2005) 23:41-51. doi: 10.1016/j.immuni.2005.05.010

40. Nimmerjahn F, Lux A, Albert H, Woigk M, Lehmann C, Dudziak D, et al. FcgammaRIV deletion reveals its central role for IgG2a and IgG2b activity in vivo. Proc Natl Acad Sci USA. (2010) 107:19396-401. doi: 10.1073/pnas.1014515107

41. Karsten CM, Pandey MK, Figge J, Kilchenstein R, Taylor PR, Rosas M, et al. Anti-inflammatory activity of IgG1 mediated by Fc galactosylation and association of FcgammaRIIB and dectin-1. Nat Med. (2012) 18:1401-6. doi: $10.1038 / \mathrm{nm} .2862$

42. Bournazos S, Klein F, Pietzsch J, Seaman MS, Nussenzweig MC, Ravetch JV. Broadly neutralizing anti-HIV-1 antibodies require Fc effector functions for in vivo activity. Cell. (2014) 158:1243-53. doi: 10.1016/j.cell.2014.08.023

43. Dilillo DJ, Tan GS, Palese P, Ravetch JV. Broadly neutralizing hemagglutinin stalk-specific antibodies require FcgammaR interactions for protection against influenza virus in vivo. Nat Med. (2014) 20:143-51. doi: 10.1038/nm.3443

44. DiLillo DJ, Palese P, Wilson PC, Ravetch JV. Broadly neutralizing antiinfluenza antibodies require $\mathrm{Fc}$ receptor engagement for in vivo protection. J Clin Invest. (2016) 126:605-10. doi: 10.1172/JCI84428

45. Schmitz N, Beerli RR, Bauer M, Jegerlehner A, Dietmeier K, Maudrich M, et al. Universal vaccine against influenza virus: linking TLR signaling to anti-viral protection. Eur J Immunol. (2012) 42:863-9. doi: 10.1002/eji.2010 41225

46. Van den Hoecke S, Ehrhardt K, Kolpe A, El Bakkouri K, Deng L, Grootaert H, et al. Hierarchical and redundant roles of activating FcgammaRs in protection against influenza disease by M2e-specific IgG1 and IgG2a antibodies. J Virol. (2017) 91:e02500-16. doi: 10.1128/JVI.02500-16

47. Yates NL, Liao HX, Fong Y, deCamp A, Vandergrift NA, Williams WT, et al. Vaccine-induced Env V1-V2 IgG3 correlates with lower HIV-1 infection risk and declines soon after vaccination. Sci Transl Med. (2014) 6:228ra39. doi: 10.1126/scitranslmed.3007730

48. Yoshida $\mathrm{T}$, Imai $\mathrm{T}$, Kakizaki $\mathrm{M}$, Nishimura $\mathrm{M}$, Takagi $\mathrm{S}$, Yoshie O. Identification of single C motif-1/lymphotactin receptor XCR1. J Biol Chem. (1998) 273:16551-4. doi: 10.1074/jbc.273.26.16551

49. Dorner BG, Dorner MB, Zhou X, Opitz C, Mora A, Guttler S, et al. Selective expression of the chemokine receptor XCR1 on cross-presenting dendritic cells determines cooperation with CD8+ T cells. Immunity. (2009) 31:823-33. doi: 10.1016/j.immuni.2009.08.027

50. Fossum E, Grodeland G, Terhorst D, Tveita AA, Vikse E, Mjaaland S, et al. Vaccine molecules targeting Xcr1 on cross-presenting DCs induce protective CD8+ T-cell responses against influenza virus. Eur J Immunol. (2015) 45:62435. doi: 10.1002/eji.201445080

51. Gudjonsson A, Lysen A, Balan S, Sundvold-Gjerstad V, ArnoldSchrauf C, Richter L, et al. Targeting influenza virus hemagglutinin to $\mathrm{Xcr} 1+$ dendritic cells in the absence of receptor-mediated endocytosis enhances protective antibody responses. J Immunol. (2017) 198:2785-95. doi: 10.4049/jimmunol.1601881

52. Braathen R, Spång HCL, Lindeberg MM, Fossum E, Grødeland G, Fredriksen $\mathrm{AB}$ et al. The Magnitude and IgG subclass of antibodies elicited by targeted DNA vaccines are influenced by specificity for APC surface molecules. ImmunoHorizons. 2 (2018) 1:38-53. doi: 10.4049/immunohorizons.1700038 
53. Boscardin SB, Hafalla JC, Masilamani RF, Kamphorst AO, Zebroski HA, Rai U, et al, Antigen targeting to dendritic cells elicits long-lived $\mathrm{T}$ cell help for antibody responses. J Exp Med. (2006) 203:599-606. doi: $10.1084 /$ jem.20051639

54. Lahoud MH, Ahmet F, Kitsoulis S, Wan SS, Vremec D, Lee CN, et al. Targeting antigen to mouse dendritic cells via Clec9A induces potent CD4 T cell responses biased toward a follicular helper phenotype. J Immunol. (2011) 187:842-50. doi: 10.4049/jimmunol.1101176

55. Chappell CP, Draves KE, Giltiay NV, Clark EA. Extrafollicular B cell activation by marginal zone dendritic cells drives $\mathrm{T}$ cell-dependent antibody responses. J Exp Med. (2012) 209:1825-1840. doi: 10.1084/jem.20120774

56. Shin C, Han J-A, Choi B, Cho K, Do Y, Ryu S. Intrinsic features of the CD8 $\alpha$ dendritic cell subset in inducing functional $\mathrm{T}$ follicular helper cells. Immunol Lett. (2016) 172:21-28. doi: 10.1016/j.imlet.2016.01.009

57. Do Y, Koh H, Park CG, Dudziak D, Seo P, Mehandru S, et al. Targeting of LcrV virulence protein from Yersinia pestis to dendritic cells protects mice against pneumonic plague. Eur J Immunol. (2010) 40:2791-6. doi: 10.1002/eji.201040511

58. Corbett AJ, Caminschi I, McKenzie BS, Brady JL, Wright MD, Mottram PL, et al. Antigen delivery via two molecules on the CD8- dendritic cell subset induces humoral immunity in the absence of conventional "danger". Eur J Immunol. (2005) 35:2815-25. doi: 10.1002/eji.200526100

59. Grodeland G, Mjaaland S, Roux KH, Fredriksen AB, Bogen B. DNA vaccine that targets hemagglutinin to MHC class II molecules rapidly induces antibody-mediated protection against influenza. J Immunol. (2013) 191:322131. doi: 10.4049/jimmunol.1300504

60. Guilliams M, Dutertre CA, Scott CL, McGovern N, Sichien D, Chakarov S, et al. Unsupervised high-dimensional analysis aligns dendritic cells across tissues and species. Immunity. (2016) 45:669-84. doi: 10.1016/j.immuni.2016.08.015

61. Heidkamp GF, Sander J, Lehmann CHK, Heger L, Eissing N, Baranska A, et al. Human lymphoid organ dendritic cell identity is predominantly dictated by ontogeny, not tissue microenvironment. Sci Immunol. (2016). 1:eaai7677. doi: 10.1126/sciimmunol.aai7677

62. Grodeland G, Fossum E, Bogen B. Polarizing T and B cell responses by APC-targeted subunit vaccines. Front Immunol. (2015) 6:367. doi: $10.3389 /$ fimmu.2015.00367

63. Lysen A, Braathen R, Gudjonsson A, Tesfaye DY, Bogen B, Fossum E. Dendritic cell targeted Ccl3- and Xcl1-fusion DNA vaccines differ in induced immune responses and optimal delivery site. Sci Rep. (2019) 9:1820. doi: 10.1038/s41598-018-38080-7

64. Langlet C, Tamoutounour S, Henri S, Luche H, Ardouin L, Gregoire C, et al. CD64 expression distinguishes monocyte-derived and conventional dendritic cells and reveals their distinct role during intramuscular immunization. $J$ Immunol. (2012) 188:1751-60. doi: 10.4049/jimmunol.1102744

65. Steinman RM. Decisions about dendritic cells: past, present, and future. Annu Rev Immunol. (2012) 30:1-22. doi: 10.1146/annurev-immunol-100311-102839

66. Steinman RM, Bona C, Inaba K. Dendritic Cells: Important Adjuvants During DNA Vaccination. Georgetown, TX: Landes Bioscience, (2002).

67. Lee MSJ, Natsume-Kitatani Y, Temizoz B, Fujita Y, Konishi A, Matsuda K, et al. B cell-intrinsic MyD88 signaling controls IFN-gamma-mediated early IgG2c class switching in mice in response to a particulate adjuvant. Eur Immunol J. (2019). doi: 10.1002/eji.201848084 [Epub ahead of print].

68. Neubert K, Lehmann CH, Heger L, Baranska A, Staedtler AM, Buchholz VR, et al. Antigen delivery to $\mathrm{CD} 11 \mathrm{c}+\mathrm{CD} 8$ - dendritic cells induces protective immune responses against experimental melanoma in mice in vivo. $J$ Immunol. (2014) 192:5830-8. doi: 10.4049/jimmunol.1300975

69. Park HY, Tan PS, Kavishna R, Ker A, Lu J, Chan CEZ, et al. Enhancing vaccine antibody responses by targeting Clec9A on dendritic cells. NPJ Vacc. (2017) 2:31. doi: 10.1038/s41541-017-0033-5

70. Kato Y, Zaid A, Davey GM, Mueller SN, Nutt SL, Zotos D, et al. Targeting antigen to Clec9A primes follicular Th cell memory responses capable of robust recall. J Immunol. (2015) 195:1006-14. doi: 10.4049/jimmunol.1500767

71. White AL, Tutt AL, James S, Wilkinson KA, Castro FVV, Dixon SV, et al. Ligation of $\mathrm{CD} 11 \mathrm{c}$ during vaccination promotes germinal centre induction and robust humoral responses without adjuvant. Immunology. (2010) 131:141-51. doi: 10.1111/j.1365-2567.2010.03285.x
72. Chaplin JW, Kasahara S, Clark EA, Ledbetter JA. Anti-CD180 (RP105) activates $\mathrm{B}$ cells to rapidly produce polyclonal Ig via a $\mathrm{T}$ cell and MyD88-independent pathway. J Immunol. (2011) 187:4199-209. doi: 10.4049/jimmunol.1100198

73. Chaplin JW, Chappell CP, Clark EA. Targeting antigens to CD180 rapidly induces antigen-specific IgG, affinity maturation, and immunological memory. J Exp Med. (2013) 210:2135-46. doi: 10.1084/jem.201 30188

74. Andersen TK, Huszthy PC, Gopalakrishnan RP, Jacobsen JT, Fauskanger M, Tveita AA, et al. Enhanced germinal center reaction by targeting vaccine antigen to major histocompatibility complex class II molecules. NPJ Vaccines. (2019) 4:9. doi: 10.1038/s41541-019-0101-0

75. Tam HH, Melo MB, Kang M, Pelet JM, Ruda VM, Foley MH, et al. Sustained antigen availability during germinal center initiation enhances antibody responses to vaccination. Proc Natl Acad Sci USA. (2016) 113:E6639-48. doi: $10.1073 /$ pnas. 1606050113

76. Hu JK, Crampton JC, Cupo A, Ketas T, van Gils MJ, Sliepen K, et al. Murine antibody responses to cleaved soluble HIV-1 envelope trimers are highly restricted in specificity. J Virol. (2015) 89:10383-98. doi: 10.1128/JVI. 01653-15

77. Pauthner M, Havenar-Daughton C, Sok D, Nkolola JP, Bastidas R, Boopathy AV, et al. Elicitation of robust tier 2 neutralizing antibody responses in nonhuman primates by HIV envelope trimer immunization using optimized approaches. Immunity. (2017) 46:1073-88 e6. doi: 10.1016/j.immuni.2017.05.007

78. Cirelli KM, Carnathan DG, Nogal B, Martin JT, Rodriguez OL, Upadhyay AA, et al. Slow delivery immunization enhances HIV neutralizing antibody and germinal center responses via modulation of immunodominance. Cell. (2019) 177:1153-71 e28. doi: 10.1101/432666

79. Cirelli KM, Crotty S. Germinal center enhancement by extended antigen availability. Curr Opin Immunol. (2017) 47:64-9. doi: 10.1016/j.coi.2017.06.008

80. Gudjonsson A, Andersen TK, Sundvold-Gjerstad V, Bogen B, Fossum E. Endocytosis deficient murine Xcl1-fusion vaccine enhances protective antibody responses in mice. Front Immunol. 10:1086. (2019). doi: 10.3389/fimmu.2019.01086

81. Qi H, Egen JG, Huang AY, Germain RN. Extrafollicular activation of lymph node B cells by antigen-bearing dendritic cells. Science. (2006) 312:1672-6. doi: $10.1126 /$ science. 1125703

82. Crozat K, Guiton R, Contreras V, Feuillet V, Dutertre CA, Ventre E, et al. The XC chemokine receptor 1 is a conserved selective marker of mammalian cells homologous to mouse CD8alpha+ dendritic cells. J Exp Med. (2010) 207:1283-92. doi: 10.1084/jem.20100223

83. Bachem A, Guttler S, Hartung E, Ebstein F, Schaefer M, Tannert A, et al. Superior antigen cross-presentation and XCR1 expression define human $\mathrm{CD} 11 \mathrm{c}+\mathrm{CD} 141+$ cells as homologues of mouse CD8+ dendritic cells. J Exp Med. (2010) 207:1273-81. doi: 10.1084/jem.2 0100348

84. Haniffa M, Shin A, Bigley V, McGovern N, Teo P, See P, et al. Human tissues contain CD141hi cross-presenting dendritic cells with functional homology to mouse CD103+ nonlymphoid dendritic cells. Immunity. (2012) 37:60-73. doi: 10.1016/j.immuni.2012.04.012

85. Caminschi I, Proietto AI, Ahmet F, Kitsoulis S, Shin Teh J, Lo JC, et al. The dendritic cell subtype-restricted C-type lectin Clec9A is a target for vaccine enhancement. Blood. (2008) 112:3264-73. doi: 10.1182/blood-2008-05-155176

86. Huysamen C, Willment JA, Dennehy KM, Brown GD. CLEC9A is a novel activation C-type lectin-like receptor expressed on BDCA3+ dendritic cells and a subset of monocytes. J Biol Chem. (2008) 283:16693-701. doi: 10.1074/jbc.M709923200

87. Sancho D, Joffre OP, Keller AM, Rogers NC, Martinez D, Hernanz-Falcon P, et al. Identification of a dendritic cell receptor that couples sensing of necrosis to immunity. Nature. (2009) 458:899-903. doi: 10.1038/nature07750

88. Kato M, McDonald KJ, Khan S, Ross IL, Vuckovic S, Chen K, et al. Expression of human DEC-205 (CD205) multilectin receptor on leukocytes. Int Immunol. (2006) 18:857-69. doi: 10.1093/intimm/dxl022

89. Segura E, Durand M, Amigorena S. Similar antigen cross-presentation capacity and phagocytic functions in all freshly isolated human 
lymphoid organ-resident dendritic cells. J Exp Med. (2013) 210:1035-47. doi: 10.1084/jem.20121103

90. Sittig SP, Bakdash G, Weiden J, Skold AE, Tel J, Figdor CG, et al. A comparative study of the $\mathrm{T}$ cell stimulatory and polarizing capacity of human primary blood dendritic cell subsets. Mediators Inflamm. (2016) 2016:3605643. doi: 10.1155/2016/3605643

91. Nizzoli G, Krietsch J, Weick A, Steinfelder S, Facciotti F, Gruarin P, et al. Human CD1c+ dendritic cells secrete high levels of IL-12 and potently prime cytotoxic T-cell responses. Blood. (2013) 122:932-42. doi: 10.1182/blood-2013-04-495424

92. Dhodapkar MV, Sznol M, Zhao B, Wang D, Carvajal RD, Keohan ML, et al. Induction of antigen-specific immunity with a vaccine targeting NY-ESO1 to the dendritic cell receptor DEC-205. Sci Transl Med. (2014) 6:232ra51. doi: 10.1126/scitranslmed.3008068

93. Li J, Ahmet F, Sullivan LC, Brooks AG, Kent SJ, De Rose R, et al. Antibodies targeting Clec9A promote strong humoral immunity without adjuvant in mice and non-human primates. Eur J Immunol. (2015) 45:854-64. doi: 10.1002/eji.201445127

94. Deloizy C, Fossum E, Barnier-Quer C, Urien C, Chrun T, Duval A, et al. The anti-influenza M2e antibody response is promoted by XCR1 targeting in pig skin. Sci Rep. (2017) 7:7639. doi: 10.1038/s41598-017-07372-9
95. Bernelin-Cottet C, Deloizy C, Stanek O, Barc C, Bouguyon E, Urien C, et al. A universal influenza vaccine can lead to disease exacerbation or viral control depending on delivery strategies. Front Immunol. (2016) 7:641. doi: $10.3389 /$ fimmu.2016.00641

Conflict of Interest Statement: The TTO office of Oslo University and Oslo University Hospital has filed several patents on the use of Vaccibodies, on which $\mathrm{BB}$ is an inventor. $\mathrm{BB}$ is head of the scientific advisory board of the Vaccibody Company and holds shares in the company.

The remaining authors declare that the research was conducted in the absence of any commercial or financial relationships that could be construed as a potential conflict of interest.

Copyright (C) 2019 Tesfaye, Gudjonsson, Bogen and Fossum. This is an open-access article distributed under the terms of the Creative Commons Attribution License (CC $B Y)$. The use, distribution or reproduction in other forums is permitted, provided the original author(s) and the copyright owner(s) are credited and that the original publication in this journal is cited, in accordance with accepted academic practice. No use, distribution or reproduction is permitted which does not comply with these terms. 